\title{
Spontaneous resolution of a traumatic cataract in a patient with an open-globe ocular injury: a case report
}

\author{
Yu-ting Zhang ${ }^{\dagger}$, Li-qun Dư ${ }^{\dagger}$, Mei Liu and Jing Zhu* (D)
}

\begin{abstract}
Background: We report a case of spontaneous resolution of a traumatic cataract in a patient with an open-globe ocular injury. This case highlights the importance of conservative management in these types of cases, as excellent visual outcome is possible without invasive surgical intervention.

Case presentation: A 13-year-old boy presented with a corneal laceration in the left eye caused by a neuter pen. He underwent emergency repair of the corneal laceration under general anesthesia, and at 3 days post-op, a dense posterior cortical cataract was observed. Based on the patient's age and normal visual development, in addition to preserving accommodative potential, the patient received conservative management and follow-up. Interestingly, the cataract spontaneously resolved over the following 9 months and the corrected distance visual acuity in the injured eye was restored from finger counting at $50 \mathrm{~cm}$, to 20/25 +3.

Conclusions: To optimize treatment in pediatric traumatic cataract, several critical factors such as age, visual development and the preservation of accommodative potential, need to be comprehensively considered. Conservative management with lens preservation is important to consider in young, traumatic cataract patients where invasive surgical intervention may not be required.
\end{abstract}

Keywords: Pediatric traumatic cataract, open-globe injury, conservative cataract management, spontaneous resolution, Posterior cortical cataract, Case report

\section{Background}

Spontaneous resolution of posterior cortical cataract (PCC) has been reported previously in cases where the cataract is caused by uncontrolled acute hyperglycemia [1] or transient feathering of the lens after intraocular gas tamponade [2]. In the case of traumatic cataracts, spontaneous reversal of PCC mainly occurs with mild or limited ocular injury, such as mild blunt contusion or small intralenticular foreign body [3, 4]. In severe openglobe ocular injury cases, spontaneous resolution of extensive dense PCC is rare [5], and cataract extraction,

\footnotetext{
* Correspondence: 123985117@qq.com

${ }^{\dagger}$ Yu-ting Zhang and Li-qun Du contributed equally to this work. Department of Ophthalmology, Qilu Hospital of Shandong University, 107\#, Wenhua Xi Road, Jinan, Shandong 250012, PR China
}

usually in combination with intraocular lens implantation, is required for vision correction $[6,7]$.

Here we report an unusual, spontaneous resolution of a dense PCC in a patient with severe open-globe ocular injury. Surprisingly, the patient achieved excellent visual outcome without surgical intervention.

\section{Case presentation}

A 13-year-old boy presented to us an hour after sustaining an injury to his left eye from a red neuter pen. On examination, uncorrected visual acuity was $20 / 40$ in the right eye and finger counting at $50 \mathrm{~cm}$ in the left eye. Corrected distance visual acuity (CDVA) was 20/20 with a refraction of $-1.50-2.00 \times 001$ in the right eye, and no improvement in the left eye. Slit-lamp examination of

(c) The Author(s). 2020 Open Access This article is licensed under a Creative Commons Attribution 4.0 International License, which permits use, sharing, adaptation, distribution and reproduction in any medium or format, as long as you give appropriate credit to the original author(s) and the source, provide a link to the Creative Commons licence, and indicate if changes were made. The images or other third party material in this article are included in the article's Creative Commons licence, unless indicated otherwise in a credit line to the material. If material is not included in the article's Creative Commons licence and your intended use is not permitted by statutory regulation or exceeds the permitted use, you will need to obtain permission directly from the copyright holder. To view a copy of this licence, visit http://creativecommons.org/licenses/by/4.0/ The Creative Commons Public Domain Dedication waiver (http://creativecommons.org/publicdomain/zero/1.0/) applies to the data made available in this article, unless otherwise stated in a credit line to the data. 
the left eye showed a full-thickness corneal laceration from 4 to 8 o'clock, inside the limbus, with iris prolapse. Anterior chamber depth was shallow, and an exudative membrane was noted on the anterior lens surface (Fig. 1). This patient underwent emergency repair of the corneal laceration under general anesthesia. The laceration was repaired using an interrupted suture technique with 100 nylon sutures, and the exudative membrane was removed using microscopic tweezers. The anterior lenticular capsule appeared intact. Post-operatively, the patient received conventional topical steroid therapy (Tobradex eyedrops 4 times a day and Tobradex eye ointment at bedtime) to reduce inflammation. Three days after surgery, a rosette-shaped PCC was observed in the left eye, while the anterior capsule and lens nucleus were still intact and transparent (Fig. 2a). The lens of the right eye was normal. Within another 3 days, the PCC increased in density and covered the whole pupillary area. The CDVA was 20/133 in the left eye (refraction of Pl-4.00 x 070). Ophthalmic B scan ultrasound examination showed increased echo of the lenticular posterior capsule with artifacts (Fig. 2b). Fundoscopic examination of the left eye were difficult to perform secondary to the cataract, however, no gross abnormalities were noted (Fig. 2c). Options for management of the cataract, including cataract surgery, were discussed with the patient's father. Considering his age and good visual development, we agreed upon conservative observation. The patient returned for cataract follow-up bi-weekly, and waited for an appropriate time for surgery. At the one-month follow-up, we observed that the size of the PCC began to decrease (Fig. 2d, e). Nine months later, only a faint imprint of the original cataract remained

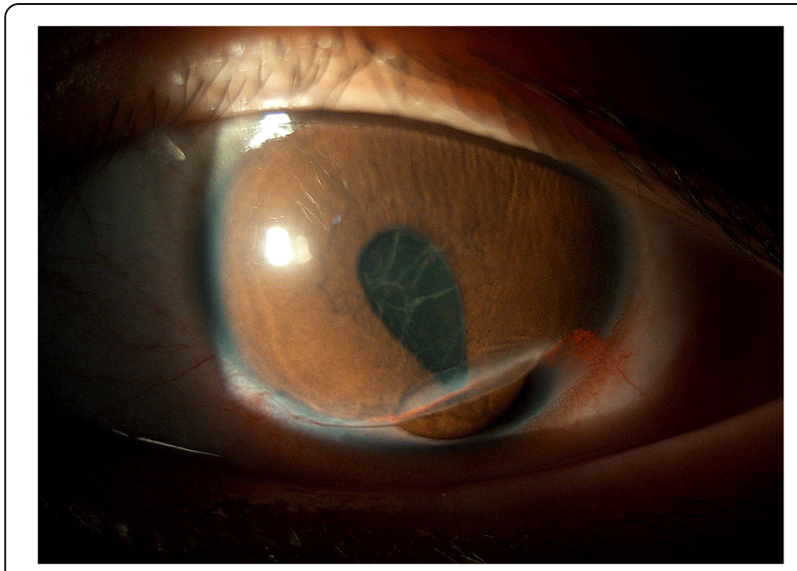

Fig. 1 Preoperative slit lamp photograph of the patient's left eye. There was a full-thickness corneal laceration from 4 to 8 o'clock with iris prolapse and the anterior surface of the lens was covered with an exudative membrane and CDVA was restored to $20 / 25^{+3}$ with a refraction of Pl-1.50 $\times 070$ in the left eye (Fig. $2 \mathrm{f}$ ).

\section{Discussion and conclusions}

Rapidly developing traumatic cataract is a common manifestation in ocular injury cases, such as intralenticular foreign body, contusive injury and open-globe ocular injury. The lens epithelium and fiber cells become damaged during injury, disrupting the integrity and permeability of the lenticular capsule. This leads to an influx of aqueous humor into the lens lamella, causing it to swell and irreversibly opacify secondary to the denaturation of lens proteins [8]. However, if the lenticular capsule damage is limited, the proliferative lens epithelium can reseal the wound without progressive cataract formation, and in rare cases, allow cataract resolution [3]. Brini A. et al. inferred that the resorption of small superficial lens opacities may occur in a pseudo-lysosomal fashion [9]. Neumayer T. et al. observed the changes and disappearance of lens vacuoles within 4 weeks in PCC patients, which might partially explain PCC spontaneous regression [10].

In open-globe injury cases, cataract formation results from direct impact, and the location of the most dense opacity commonly indicates the point of greatest impact $[3,11]$. Paradoxically, in our case, cataract density was worst at the posterior cortex and not the anterior part of lens. Previous reports indicate that in blunt ocular trauma, posterior capsular rupture is more likely to appear in children and young adults [12, 13]. Wolter proposed that the absence of a sclerotic nucleus and strong zonular fibers in children and teenagers may allow the force of impact to transmit to the posterior part of lens [14]. We hypothesize that in this open-globe injury case, the PCC is secondary to indirect shock waves stemming from impact.

In young cataract patients, treatment options are more debated and require further consideration. It is known that the critical period of eye development ranges from 2 to 6 months of age, and emmetropization is generally achieved by 9 years of age [15]. To avoid amblyopia, some ophthalmologists recommend early surgical intervention for pediatric ocular traumatic cataracts, and in simple PCC cases without corneal or retinal injury, cataract extraction with intraocular lens implantation can restore excellent visual acuity [6, 7]. However, in young patients, cataract extraction also results in the loss of accommodation. For children, loss of accommodation and physiologic hyperopic reserve might affect the progress of emmetropization [16]. For teenagers, this loss of accommodation aggravates asthenopia during near work in daily life. In our case, due to the patient's age and normal visual development, we selected the 


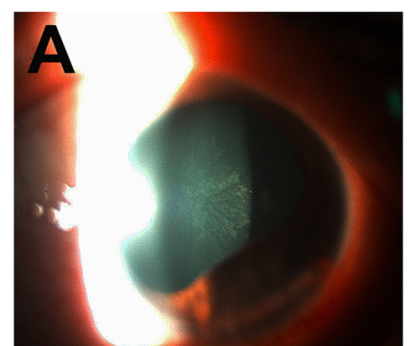

3 days after operation

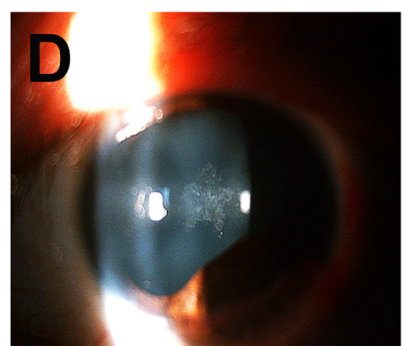

1 months after operation

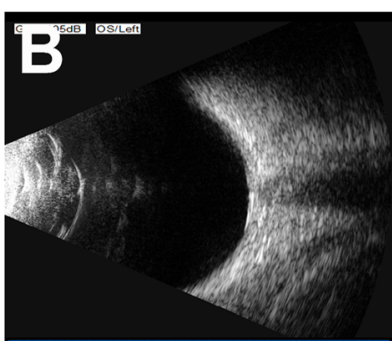

ophthalmic B scan
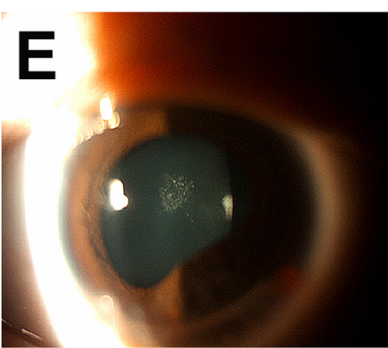

3 months after operation

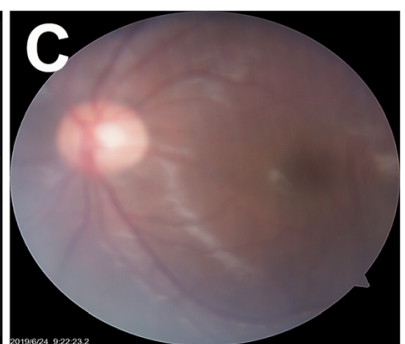

Fundus photography
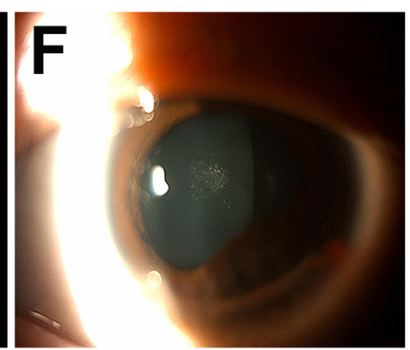

9 months after operation

Fig. 2 The change of PCC at different time during the spontaneous resolution. a 3 days after surgery, a rosette-shaped PCC was observed, $\mathbf{b}$ Ophthalmic B scan 6 days after surgery, $\mathbf{c}$ Fundus photography 6 days after surgery, $\mathbf{d}$, e The size of the PCC began to decrease from 1 month after surgery, $\mathbf{f} 9$ months after surgery, only a faint imprint of the original cataract remained

conservative approach of observation and obtained an excellent prognosis.

Our case highlights that several critical factors such as age, visual development and the preservation of accommodative potential, need to be weighed to optimize the treatment of pediatric ocular traumatic cataracts. Importantly, conservative observation may greatly benefit the young patient by avoiding unnecessary invasive surgical intervention and subsequent loss of accommodation.

\section{Abbreviations}

CDVA: Corrected distance visual acuity; PCC: Posterior cortical cataract

\section{Acknowledgements}

We would like to thank Editage (www.editage.cn) for English language editing.

\section{Authors' contributions}

ZYT and DLQ were major contributors in writing the manuscript and made substantial contributions to the conception of the report. LM collected and interpreted the clinical data of the patient. ZJ was the total director of the study and assigned the roles to the authors. All authors read and approved the final manuscript.

\section{Funding}

This study was supported by a grant from the National Natural Science Fund of China (81500696) which affords part of the fee for the patient's follow-up and the collection of data.

\section{Availability of data and materials}

The datasets used and/or analysed during the current study are available from the corresponding author on reasonable request.

\section{Ethics approval and consent to participate}

This study was approved by the Medical Ethics Review Board at Qilu Hospital of Shandong University. All procedures performed in the patient were in accordance with the ethical standards of the institutional and/or national research committee and with the 1964 Helsinki declaration and its later amendments or comparable ethical standards. Informed consent was obtained from the patient's father for reporting this case.

\section{Consent for publication}

Written informed consent was obtained from the patient's father for publication of this case report and any accompanying images.

\section{Competing interests}

The authors declare that they have no competing interests.

Received: 30 April 2020 Accepted: 6 July 2020

Published online: 13 July 2020

\section{References}

1. Ramkumar $\mathrm{H}$, Basti $\mathrm{S}$. Reversal of bilateral rosette cataracts with glycemic control. ScientificWorldJournal. 2008:8:1150-1.

2. Petermeier K, Szurman P, Bartz-Schmidt UK, Gekeler F. Pathophysiology of cataract formation after vitrectomy. Klin Monatsbl Augenheilkd. 2010;227(3): $175-80$.

3. Rofagha S, Day S, Winn BJ, Ou Jl, Bhisitkul RB, Chiu CS. Spontaneous resolution of a traumatic cataract caused by an intralenticular foreign body. J Cataract Refract Surg. 2008;34(6):1033-5.

4. Avasthy P, Gupta RB. Traumatic cataract. Br J Ophthalmol. 1958:42(4):240-1.

5. Moreschi C, Da Broi U, Lanzetta P. Medico-legal implications of traumatic cataract. J Forensic Legal Med. 2013;20(2):69-73.

6. Singh RB, Thakur S, Ichhpujani P. Traumatic rosette cataract. BMJ Case Rep. 2018;11(1):e227465.

7. Du Y, He W, Sun X, Lu Y, Zhu X. Traumatic cataract in children in eastern China: Shanghai pediatric cataract study. Sci Rep. 2018;8(1):2588.

8. Shah MA, Shah SM, Shah SB, Patel CG, Patel UA. Morphology of traumatic cataract: does it play a role in final visual outcome? BMJ Open. 2011;1(1): e000060. 
9. Brini A, Porte A, Stoeckel ME. Resorption of necrotic lens material by a newly formed lens capsule in certain types of cataract. Nature. 1963;200: 796-7.

10. Neumayer T, Hirnschall N, Georgopoulos M, Findl O. Natural course of posterior subcapsular cataract over a short time period. Curr Eye Res. 2017; 42(12):1604-7.

11. Bansal A, Fenerty CH. Spontaneous resolution of a rapidly Formed dense cataract following Nd: YAG laser peripheral Iridotomy in a case of Pigmentary Glaucoma. J Glaucoma. 2020;29(4):322-5.

12. Matalia J, Kasturi N, Anaspure H, Shetty BK, Matalia H. Isolated posterior capsular split limited by Weiger's ligament after blunt ocular trauma in a child mimicking posterior lenticonus. J AAPOS. 2015;19(6):557-8.

13. Lee $\mathrm{SI}$, Song $\mathrm{HC}$. A case of isolated posterior capsule rupture and traumatic cataract caused by blunt ocular trauma. Korean J Ophthalmol. 2001;15(2): $140-4$.

14. Wolter JR. Coup-contrecoup mechanism of ocularinjuries. Am Ophthalmol. 1963;56:785-96.

15. Khokhar SK, Pillay G, Dhull C, Agarwal E, Mahabir M, Aggarwal P. Pediatric cataract. Indian J Ophthalmol. 2017;65(12):1340-9.

16. Medina A. Prevention of myopia by partial correction of hyperopia: a twins study. Int Ophthalmol. 2018;38(2):577-83.

\section{Publisher's Note}

Springer Nature remains neutral with regard to jurisdictional claims in published maps and institutional affiliations.

Ready to submit your research? Choose BMC and benefit from:

- fast, convenient online submission

- thorough peer review by experienced researchers in your field

- rapid publication on acceptance

- support for research data, including large and complex data types

- gold Open Access which fosters wider collaboration and increased citations

- maximum visibility for your research: over $100 \mathrm{M}$ website views per year

At $\mathrm{BMC}$, research is always in progress.

Learn more biomedcentral.com/submissions 